\title{
Major Cause of Organ and Carcass Condemnation in Apparently Healthy Small Ruminant Slaughtered at Addis Ababa Abattoir Enterprise, Ethiopia
}

Dinku Assefa ${ }^{1}$, Elias Gezaheng ${ }^{2}$, Birhanu Abera ${ }^{3}$, Eyob Eticha ${ }^{3}$, Diriba Lemma ${ }^{3}$ and Tekle Hailemariam ${ }^{4}$

${ }^{1}$ Yem Special District Livestock and Fishery Resource Office, SNNPRS, Ethiopia

${ }^{2}$ Bale Zone Pastoral Area Development Office, Bale Robe, Ethiopia

${ }^{3}$ Asella Regional Veterinary Laboratory, Asella, Ethiopia

${ }^{4}$ Kembata Tembaro District Livestock and Fishery Resource Office, SNNPRS, Ethiopia

\begin{abstract}
Study was conducted from November 2008 to March 2009 to determine the major causes of organ and carcass condemnation and associated annual magnitude of financial loss at Addis Ababa abattoir enterprise. Out of 1052 examined sheep and goats 459 (43.6\%) livers, 307 (29.18\%) lungs, $130(12.36 \%)$ Hearts, 108 (20.27\%) kidney and $28(2.66 \%)$ carcass were condemned. The major causes of condemnation were parasite $52.24 \%$, cirrhosis $(11.2 \%)$, hepatitis $(9.2 \%)$ and mechanical damage $(8.12 \%)$ for liver; pneumonia $(32.2 \%)$, emphysema $(19.5 \%)$ and hydatidosis (15.9\%) for lung; pericarditis (43.07\%), calcification (17.7), Abscess (5.4\%), Cysticercus ovis $(8.4 \%)$ and other $(25.4 \%)$ for heart; nephritis $(30.5 \%)$ for kidneys, abscess $(50 \%)$, bruising $(29 \%)$ and other causes for carcasses. Rate of condemnation due to hydatidosis was higher in the lungs ( $4.3 \%$ in sheep and $5.0 \%$ in goats) than in the liver $(3.3 \%$ in sheep and $3.4 \%$ in goats) significant higher rate of liver, lung, heart, kidney and carcass condemnation were not observed between age groups $(p>0.05)$, but significantly higher rate of organ and carcass condemnation were observed with in sex group of sheep $(P<0.05)$. However significant difference in the rate of organ and carcasses condemned were not observed by species of the animals $(p>0.05)$. Total annual loss due to organ and carcass condemnation was estimated one million Ethiopian Birr (90909.09 USD). Result of the present work warrant immediate need for the prevention of causes of organ and carcass condemnation and pathological abnormalities through development of and animal health delivery, enforcement of slaughter policy, education of sheep and goat traders, and training of slaughter house personnel on standard slaughter operations.
\end{abstract}

Keywords: Abattoir; Addis Ababa; Carcass; Condemnation; Financial loss; Goats; Organ; Sheep

\section{Introduction}

Ethiopia, with over 42 million head, has the third largest number of sheep and goat among African nations and rank eighth in the world [1]. Small ruminant (sheep and goats) are among economically important livestock in Ethiopia. There are about 25.5 million sheep and 22.78 million goats [2]. They contribute a quarter of domestic meat consumption, about half of the domestic wool requirements about $40 \%$ of fresh skin and $92 \%$ of the value of semi-processed skin and hide export trade it is estimated that 1,078.000 sheep and 1.128.000 goats are used in Ethiopia for domestic consumption annually.

Many important livestock diseases that inflict major socio - economic losses in Ethiopia occur every year. Annual disease losses amount to $8-10 \%, 14-16 \%$ and $11-13 \%$ of cattle, sheep and goats populations respectively. It is estimated that some 700 Million Birr (1 US\$=9.2) is lost annually due to helminthes (internal parasite) infestation of domestic animals. Besides affecting the quantity and quality of livestock products, the prevalence of infectious and economically important animal disease in Ethiopia excludes the country from profitable international markets; there by greatly reducing the country's foreign exchange earnings poor husbandry practice and inadequate veterinary services are of the major factors favoring the expansion of livestock diseases [1].

However, each year a significant loss result from death of animals, inferior weight gain, condemnation of edible organs and carcass at slaughter house. This production loss to the livestock industry is estimated at more than 900 million USD annually [3]. A recent study conducted at HELMEX abattoir, Debre Zeit, Ethiopia indicate the annual direct financial loss form international and domestic markets due to organ and carcass condemnations from different pathological lesions was estimated at 2.7 million Ethiopian Birr (312,655 USD) annually. This total loss could be partitioned in to the loss incurred due to disease which amounted to $187,868.6$ USD and the rest, $124,686.4$ USD, was due to human factors either as a result of mishandling of animals during transport to the slaughter house or due to faulty slaughter operations in the abattoir [4].

As the meat are the main sources of protein to human being, it should be clean and free from diseases of particular importance to the public such as tuberculosis and cysticercosis. Meat is also condemned at slaughter house to break the chain of some zoonoses which are not transmitted to man directly via meat like hydatidosis and other important diseases of animals such as fasciolosis $[5,6]$

Yet meat is also condemned from human consumption because of aesthetic values caused by diseases and mechanical damage during slaughtering operation procedures [7]. A report of the prevalence of

*Corresponding author: Birhanu Abera, Asella Regional Veterinary Laboratory, Asella, Ethiopia, Tel: +251913333944; E-mail: birhanuabera27@yahoo.com

Received December 09, 2016; Accepted January 19, 2017; Published January 21, 2017

Citation: Assefa D, Gezaheng E, Abera B, Eticha E, Lemma D, et al. (2017) Major Cause of Organ and Carcass Condemnation in Apparently Healthy Small Ruminant Slaughtered at Addis Ababa Abattoir Enterprise, Ethiopia. J Vet Sci Technol 8: 419. doi: 10.4172/2157-7579.1000419

Copyright: ( 2017 Assefa D, et al. This is an open-access article distributed under the terms of the Creative Commons Attribution License, which permits unrestricted use, distribution, and reproduction in any medium, provided the original author and source are credited. 
Echinococcus granulosis (adult stage of the hydatid cyst) in dogs indicated $25.45 \%$ [8]. The presence of hydatidasis was also reported in man in the south-west Ethiopia. Hydatidosis is maintained as a major zoonotic disease in the country because small ruminants are mainly slaughtered at the backyard for home consumption without any veterinary inspection, the absence of rigorous and enforced meat inspection legislation and long standing habit of feeding offal to dogs. The presence of large number of stray dogs throughout the country exacerbates the problem. However, there is no information describing the causes and associated magnitude of organs and carcass condemnation in slaughtered sheep and goat at Addis Ababa Abattoir Enterprise. Determination of the causes and magnitude of organ and carcass condemnation in these animals using abattoir surveillance by considering associated risk factors for evaluation of associated economic loss are needed where economic realities often determine the type and scope of preventive measures to be used. Therefore the objectives of this study were; to determine the major causes of organ and carcass condemnation in apparently healthy sheep and goat slaughtered and to estimate the associated magnitude of economic loss at Addis Ababa Abattoir enterprise.

\section{Materials and Methods}

\section{Study area}

The study was conducted at Addis Ababa Abattoir Enterprise, Ethiopia, from December 2008 to April 2009. Where cattle, small ruminant and swine are slaughtered. The average annual slaughtered animals where 36,000 sheep and 18,000 goat according to animal report of the abattoir of LMA, 2009 [9]. The obtained beef, mutton, lamb, goat meat and edible organs like liver, lung, heart and kidney, was distributed to the customers. Addis Ababa is the capital city and administrative center for the Federal Democratic Republic of Ethiopia. Geographically, the area is located with in an altitude of about 2,400 $\mathrm{m}$ above sea level and receives a mean annual rainfall of season 18000 $\mathrm{mm}$ in bimodal with average minimum and maximum temperatures are $10.7^{\circ} \mathrm{C}$ and $25.6^{\circ} \mathrm{C}$ respectively [10].

\section{Study animals}

A total of 1052 animals comprising ( 600 sheep and 452 goats) where randomly selected and identified by species, age, and sex during ante mortem inspection. The animals were originating from different areas of the country (Arsi, Bale, Afar, Shoa, Ogaden, Wollo, Omo, Jimma, and Borena) representing different agro ecological zones (highland, semi arid and arid). It was impossible to track back the origin of each animal as they were being mixed before they arrive at the abattoirs. Animals were transported to the abattoir using vehicles and on foot. Age grouping in to young for goats less than 1 year and sheep less than 1.25 years while adult for goat more that 1 year and sheep more than 1.25 years [11]. Random sample size distributions were as shown in Table 1 below.

\section{Abattoir survey}

Detailed meat inspection procedure were applied and examination

\begin{tabular}{|c|c|c|c|c|c|}
\hline \multirow{2}{*}{ Species } & \multicolumn{4}{|c|}{ Sex } & \multirow{2}{*}{ Tote } \\
\cline { 2 - 6 } & $\begin{array}{c}\text { Young (\%) } \\
\text { (\%) }\end{array}$ & Adult (\%) & Young (\%) & Adult (\%) & Fomale \\
\hline Sheep & $159(38.4)$ & $255(61.6)$ & $34(18.3)$ & $152(81.7)$ & $600(100)$ \\
\hline Goats & $111(29.5)$ & $265(70.5)$ & $17(22.4)$ & $59(77.6)$ & $452(100)$ \\
\hline Total & $270(25.6)$ & $520(49.4)$ & $51(4.9)$ & $211(19.6)$ & $1052(100)$ \\
\hline
\end{tabular}

Table 1: Number of animals examined. were done after evisceration, the liver, lung, heart, kidney and carcass were thoroughly examined by visual inspection, palpation and systematic incisions for the presence of gross pathological lesions and parasite were differentiated and judged based on guidelines on meat inspection for developing countries [7].

\section{Study design}

Cross sectional study by abattoir survey were conducted for the determination of major causes of organ and carcass condemnation in apparently healthy sheep and goat slaughtered at Addis Ababa Abattoir Enterprises by post mortem examination.

\section{Data management and statistical analysis}

Data collected during study period were entered in to Excel spreadsheet (Microsoft Excel 2007). Descriptive statistics were used to determine major cause of organ and carcass condemnation rate by using percentage. Association of the risk factors were calculated with consideration of age, sex, species and abnormalities were evaluated by person's chi-square $\left(\mathrm{x}^{2}\right)$ and differences were regarded statistically significant if $\mathrm{P}$-values were less than 0.05 .

\section{Assessment of economical losses}

To evaluate the economic losses, only the direct monetary losses due to rejection of liver, lung, heart, kidney and carcass were considered. The analysis was based on annual slaughter capacity of the abattoir considering market demand, average market price on domestic markets, and rejection rates of specific organs and carcasses. The annual slaughter rates were estimated from retrospective slaughter data recorded in the past three years. Financial losses were then computed mathematically by adapting the formula of Ogunrinade 1980 for liver [12].

$$
\mathrm{EL} \mathrm{srx}{ }^{\star} \operatorname{coy}{ }^{\star} \mathrm{Roz}
$$

Where

EL - Estimated annual economic loss due to organs and carcass condemnation from domestic market.

Srx - Annual sheep /goat slaughter rates of the abattoir.

Coy - Average cost of each sheep/goat liver/lung/Heart/Kidney/ carcass.

Roz - Condemnation rates of sheep /goat liver/bung/Kidney/ Heart/ carcass.

\section{Results}

\section{Post mortem examination}

Out of 1052 small ruminant examined during the study period, 459 (43.6\%), 307 (29.18\%), 130(12.36\%), 108 (10.27\%) and 28 (2.66\%) of all liver, lungs, hearts, kidney and carcasses, respectively, were condemned, respectively from gross abnormalities as unfit for human consumption (Table 2). The most frequently condemned organ was liver followed by the lungs. Significant difference in the rate of organs and carcasses condemned were not observed by species of animals and pathological abnormalities $(\mathrm{P}>0.05)$.

Percentage of condemnations of Liver (43.2\%), Lung (27.83\%), Heart (11.67\%), Kidney (12.33\%) and Carcass (2.5\%) in sheep like wise $(44.25 \%)(30.1 \%)(13.27 \%)(17.5 \%)$ and $(2.88 \%)$ were condemned in respective organ and carcass of goats. Regarding age insignificance was observed (Table 2) between both sexes in both study species $(\mathrm{P}>0.05)$. 
Citation: Assefa D, Gezaheng E, Abera B, Eticha E, Lemma D, et al. (2017) Major Cause of Organ and Carcass Condemnation in Apparently Healthy Small Ruminant Slaughtered at Addis Ababa Abattoir Enterprise, Ethiopia. J Vet Sci Technol 8: 419. doi: 10.4172/2157-7579.1000419

Page 3 of 7

\begin{tabular}{|c|c|c|c|c|c|c|c|}
\hline \multicolumn{2}{|c|}{ Risk factors } & $\begin{array}{l}\text { Number of } \\
\text { Examined }\end{array}$ & Liver (\%) & Lung (\%) & Heart (\%) & Kidney (\%) & Carcass (\%) \\
\hline \multirow{6}{*}{ Sheep } & Male Female & $\begin{array}{l}414 \\
186\end{array}$ & $\begin{array}{c}167(40.34) \\
92(49.46)\end{array}$ & $\begin{array}{c}103(24.88) \\
64(34.41)\end{array}$ & $\begin{array}{l}42(10.14) \\
28(15.05)\end{array}$ & $\begin{array}{l}44(10.63) \\
30(16.13)\end{array}$ & - \\
\hline & $X^{2}$ & & 4.3551 & 5.8022 & 3.009 & 3.5920 & 6.0488 \\
\hline & P-value & & 0.037 & 0.016 & 0.083 & 0.058 & 0.014 \\
\hline & $\begin{array}{l}\text { Young } \\
\text { Adult }\end{array}$ & $\begin{array}{l}193 \\
407\end{array}$ & $\begin{array}{r}2.1509 \\
0.142\end{array}$ & $\begin{array}{r}2.2654 \\
0.132\end{array}$ & $\begin{array}{c}0.9166 \\
0.338\end{array}$ & $\begin{array}{l}1.0219 \\
0.312\end{array}$ & $\begin{array}{c}2.5009 \\
0.114\end{array}$ \\
\hline & $\mathrm{X}^{2}$ & & 2.1509 & 2.2654 & 0.9166 & 1.0219 & 2.5009 \\
\hline & P-value & & 0.142 & 0.132 & 0.338 & 0.312 & 0.114 \\
\hline Total & & 600 & 259(43.17) & $167(27.8)$ & $70(11.67)$ & $74(12.3)$ & $15(2.5)$ \\
\hline \multirow{7}{*}{ Goat } & $\begin{array}{l}\text { Male } \\
\text { Female }\end{array}$ & $\begin{array}{c}376 \\
76\end{array}$ & $\begin{array}{c}156(41.49) \\
37(48.68)\end{array}$ & $\begin{array}{c}113(03.05) \\
27(35.53)\end{array}$ & $\begin{array}{l}48(12.77) \\
12(15.79)\end{array}$ & $\begin{array}{l}25(6.65) \\
9(11.84)\end{array}$ & $\begin{array}{c}12(3.19) \\
1(1.32)\end{array}$ \\
\hline & $\mathrm{X}^{2}$ & & 1.3376 & 0.8858 & 0.5020 & 2.4510 & 0.7963 \\
\hline & P-value & & 0.247 & 0.347 & 0.479 & 0.117 & 0.372 \\
\hline & Young & 129 & $63(49.2)$ & $37(28.9)$ & 12(9.4) & $11(8.6)$ & $2(1.56)$ \\
\hline & Adult & 323 & $137(42.3)$ & 103(31.8) & $48(14.8)$ & $23(7.1)$ & 11(3.4) \\
\hline & $x^{2}$ & & 3.1022 & 0.3569 & 2.3584 & 0.2948 & 1.1031 \\
\hline & P-value & & 0.078 & 0.550 & 0.125 & 0.587 & 0.294 \\
\hline Total & & 452 & $200(44.25)$ & $140(30.1)$ & $60(13.3)$ & $34(17.5)$ & $13(3.0)$ \\
\hline Overall & & 1052 & $459(43.63)$ & $307(29.2)$ & $130(12.4)$ & $108(10.3)$ & $28(2.66)$ \\
\hline
\end{tabular}

Table 2: Total condemnations of organ and carcass Rate (\%).

The frequency of liver condemnation was statistically significant difference was not observed in sheep $(259 / 600,43.17)$ and goats $(193 / 452,42.70)$ ( $p>0.05)$, but frequency of kidney condemnation, statically significant difference was not observed in condemnation of rates of lung, heath, kidney and carcass between the two species of animals $(p>0.05)$. In sheep, significantly higher $(p<0.05)$ rate of condemnation of liver, lung and carcasses were observed in the female than male, but there was significant difference were observed in sex of goats (p.0.05). No age difference was observed in the organs and carcass condemnation rates in sheep and goat $(\mathrm{P}>0.05)$ (Table 3$)$.

In sheep age difference was observed in liver cirrhosis $(0.00 \%$ in young and 8.84 in the adult) $(\mathrm{p}=0.000)$, Stilesia hepatica $(6.74 \%$ in young and $3.19 \%$ in the adult $)(\mathrm{p}=0.47)$ and mechanical damage ( $4.15 \%$ in young and $1.47 \%$ in the adult $)(p=0.043)$. In goat there was no statistically significant age difference between young and adult age categories (Table 3 ) concerning the cause of liver condemnation, except mechanical damage caused significant loss of liver in young (13.28\%) than in adult $(1.55 \%) \mathrm{p}=0.000)$.

Pneumonia was the major causes of lung rejection with a rate of $32.14 \%$ (99/308) followed by emphysema $(19.48 \%, 60 / 308)$ (Table 4$)$. There was no statistically significant difference between sheep $(117 / 600$, $29.5 \%)$ and goats $(131 / 452,28.98 \%)(\mathrm{p}>0.05)$; however, statistically significant difference was observed $(\mathrm{p}<0.05)$ between the young and adult age groups of both species in the frequency of lung condemnation from any causes, except statistically high significant difference observed in adult sheep in case of emphysema (7.86\%) than in goat $95.57 \%)$ $(\mathrm{p}=0.012)$

Significant difference between the sex groups in sheep and goats, with relation to specific causes was not observed ( $p>0.05$ ), except calcification causes significant lung condemnation in Male sheep (3.62\%) than in female sheep (1.6\%) ( $\mathrm{P}=0.007$ (Table 4); Frequency and percentage of organ and carcass condemnation by sex $(0.5 \%)$. Rate of condemnations due to hydatidosis was higher in the lung $(4.33 \%$ in sheep and 5.09\% in goats) than in the liver (3\% in sheep and 3.54\% in goats) (Table 4$)$.

Out of a total of 130 hearts condemned, pericarditis contributed $43.08 \%(56 / 130)$ followed by other unidentified causes $(24.62 \%)$ calcification (17.6\%), Cysticercus ovis (8.4\%) and abscess (5.38\%) (Table 5). No statistically significant difference was observed between the two species (p.0.05) in heart condemnation rate. In both species no statistically significant difference within age and sex categories regarding the causes of heart condemnation rare (Table 5).

Renal problems were observed in 108 pairs $(10.27 \%)$ of the total kidneys examined (Table 6). Nephritis accounting for 30.56\% (33/108) was the major pathological lesion. There was no statistically significant difference between the age, groups and sex groups ( $p>0.05)$ However nephritis caused higher rate of kidney condemnation in female goats (5.34\%) than in male sheep $(2.41 \%)(\mathrm{p}=0.018)$.

The major pathological conditions for carcass rejection from human consumption were Abscess accounting for 50\% (24/28), bruising $28.57 \%(8 / 28)$ and poor body condition (21.43\% 6/28) (Table $6)$ and other causes.

Fasciolosis caused statistically higher liver condemnations (Table $7)$ in sheep (11.67\%) than in goats $(7.3 \%)(\mathrm{P}=0.018)$, hepatitis was found to be a major cause of liver condemnation in goats $(5.31 \%)$ than in sheep $(2.83 \%)(\mathrm{p}=0.017)$, Mechanical damage has caused statistically higher rate of liver condemnation in goat $(4.87 \%)$ than in sheep $(2.33 \%)(p=0.025)$. In sheep, there was no statistically significant difference between male and female sex categories except for Fasciola species where it was significantly higher in the female sheep (15.59\%) than in the males $(9.90 \%)(p=0.045)$. In goat, there was no statistically significant difference between male and female categories regarding the cause of liver condemnation.

\section{Assessment of direct economic loss}

The annual direct financial loss from domestic markets due to 
Citation: Assefa D, Gezaheng E, Abera B, Eticha E, Lemma D, et al. (2017) Major Cause of Organ and Carcass Condemnation in Apparently Healthy Small Ruminant Slaughtered at Addis Ababa Abattoir Enterprise, Ethiopia. J Vet Sci Technol 8: 419. doi: 10.4172/2157-7579.1000419

Page 4 of 7

\begin{tabular}{|c|c|c|c|c|c|c|c|c|c|c|}
\hline \multirow[b]{3}{*}{ Abnormality } & \multicolumn{10}{|c|}{ Frequency and percentage of condemnation (\%) } \\
\hline & \multicolumn{5}{|c|}{ Sheep $(n=600)$} & \multicolumn{5}{|c|}{ Goat $(n=452)$} \\
\hline & 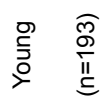 & 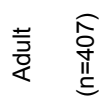 & & $\tilde{x}$ & $\begin{array}{l}\frac{0}{2} \\
\frac{10}{N 0} \\
\frac{1}{2}\end{array}$ & 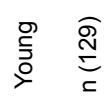 & 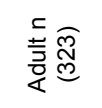 & 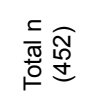 & $\tilde{x}$ & 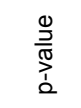 \\
\hline Fasciola & 18(9.3) & $52(12.7)$ & 70(11.7) & 1.5120 & 0.219 & $7(5.4)$ & $26(8.03$ & $33(7.3)$ & 0.9373 & 0.333 \\
\hline Cirrhosis & $0(0.0)$ & $36(8.8)$ & $36(6.0)$ & 18.161 & 0.00 & $2(1.5)$ & $11(3.4)$ & $13(2.9)$ & 1.1358 & 0.287 \\
\hline Hepatitis & $7(3.6)$ & $10(2.4)$ & $17(2.8)$ & 0.6509 & 0.420 & $7(5.4)$ & $17(5.3)$ & $24(5.3)$ & 0.0049 & 0.944 \\
\hline Stilesia hepatica & $13(6.7)$ & $13(3.2)$ & $26(4.3)$ & 3.9612 & .047 & $6(4.6)$ & $12(3.7)$ & $18(4)$ & 0.2112 & 0.646 \\
\hline Cysticercus tenicollis & $10(5.2)$ & $15(3.7)$ & $25(4.2)$ & 1.6829 & 0.431 & $5(3.9)$ & $19(5.9)$ & $24(5.3)$ & 0.7381 & 0.390 \\
\hline Calcification & $1(0.52)$ & $17(4.2)$ & $18(3.0)$ & 9.4133 & 0.052 & $2(1.5)$ & $13(4.0)$ & $15(3.3)$ & 1.0436 & 0.903 \\
\hline Mechanical damage & $8(4.2)$ & $6(1.5)$ & 14 & 4.0981 & 0.043 & $17(13.2)$ & $5(1.55)$ & $22(4.9)$ & 26.929 & 0.000 \\
\hline Hydatid cyst & $4(2.1)$ & $16(3.03)$ & $20(3.4)$ & 1.4112 & 0.703 & $4(3.1)$ & $12(3.7)$ & $16(3.5)$ & 1.4742 & 0.831 \\
\hline Abscess & $1(0.5)$ & $11(2.7)$ & $12(2.0)$ & 9.0083 & 0.109 & $4(3.0)$ & $11(3.4)$ & $15(3.3)$ & 2.8925 & 0.576 \\
\hline Other & $6(3.0)$ & $8(1.9)$ & $14(2.3)$ & & & $4(3.1)$ & $6(1.8)$ & $10(2.2)$ & & \\
\hline
\end{tabular}

Table 3: Cause of Liver condemnation by age.

\begin{tabular}{|c|c|c|c|c|c|c|c|c|c|c|}
\hline \multirow[b]{3}{*}{ Abnormality } & \multicolumn{10}{|c|}{ Frequency and percentage of condemnation (\%) } \\
\hline & \multicolumn{5}{|c|}{ Sheep $(n=600)$} & \multicolumn{5}{|c|}{ Goat(n=452) } \\
\hline & $\begin{array}{l}\text { Male \% } \\
(n=414)\end{array}$ & Female $\%(n=186)$ & $\begin{array}{l}\text { Total\% } \\
(n=600)\end{array}$ & $\mathrm{X}^{2}$ & p-value & Male\%(n=376) & $\begin{array}{c}\text { Female\% } \\
\qquad(n=76)\end{array}$ & $\begin{array}{l}\text { Total\% } \\
(n=452)\end{array}$ & $\mathrm{X}^{2}$ & p-value \\
\hline Pneumonia & $37(8.8)$ & 21(11.3) & $58(9.7)$ & 0.8138 & 0.367 & $36(9.6)$ & $5(6.6)$ & $41(9.1)$ & 0.6878 & 0.407 \\
\hline Emphysema & $22(5.3)$ & $15(8.1)$ & $37(6.2)$ & 1.6780 & 0.195 & $16(4.3)$ & $7(9.2)$ & $23(5.1)$ & 3.2142 & 0.073 \\
\hline Hydatid cyst & $14(3.4)$ & $12(6.45)$ & $26(4.3)$ & 3.7714 & 0.287 & $19(5.05)$ & $4(5.3)$ & $23(5.1)$ & 1.4742 & 0.831 \\
\hline Abscess & $3(0.7)$ & $2(1.1)$ & $5(0.83)$ & 12.2601 & 0.031 & $3(0.8)$ & $1(1.3)$ & $4(0.9)$ & 2.8925 & 0.576 \\
\hline Calcification & $15(3.6)$ & $3(1.6)$ & $18(3.0)$ & 14.2503 & 0.007 & $16(4.3)$ & $3(3.95)$ & 19(4.2) & 1.0436 & 0.903 \\
\hline Other & $13(3.14)$ & $20(10.75)$ & $33(5.5)$ & & & $14(3.7)$ & $7(5.2)$ & $21(4.6)$ & & \\
\hline Overall & $104(25.12)$ & $73(39.24)$ & $177(29.5)$ & & & $104(27.65)$ & $27(53.52)$ & $131(28.98)$ & & \\
\hline
\end{tabular}

Table 4: Frequency and percentage of condemnation Lung.

\begin{tabular}{|c|c|c|c|c|c|c|c|c|c|c|c|c|c|}
\hline \multirow{3}{*}{ 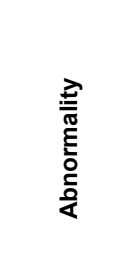 } & \multicolumn{13}{|c|}{ Frequency and distribution of lesions } \\
\hline & \multicolumn{3}{|c|}{ Sheep and goat $(n=1052)$} & \multicolumn{5}{|c|}{ Sheep $(n=600)$} & \multicolumn{5}{|c|}{ Goats $(n=452)$} \\
\hline & $\begin{array}{l}\text { Sheep } \\
n=600\end{array}$ & $\begin{array}{c}\text { Goat } \\
n=452\end{array}$ & $\begin{array}{c}\text { Total } \\
n=1052\end{array}$ & $\begin{array}{l}\text { Young } \\
n=193\end{array}$ & $\begin{array}{c}\text { Adult } \\
\mathrm{n}=407\end{array}$ & $\begin{array}{c}\text { Total } \\
n=600\end{array}$ & $\mathrm{X}^{2}$ & p-value & Youngn $=129$ & $\begin{array}{c}\text { Adult } \\
n=323\end{array}$ & Total & $\mathrm{X}^{2}$ & $\mathrm{p}$ \\
\hline Pericarditis & $31(5.1)$ & $25(5.5)$ & $56(5.3)$ & $11(5.7)$ & $20(4.9)$ & $31(5.7)$ & 0.1649 & 0.685 & $6(4.6)$ & $19(5.8)$ & $25(5.5)$ & 0.2674 & 0.605 \\
\hline Calcification & $12(2)$ & $11(2.4)$ & $23(2.2)$ & $2(1)$ & $10(2.4)$ & $12(2)$ & 9.4133 & 0.042 & $2(1.5)$ & $9(2.8)$ & $11(2.4)$ & 4.0024 & 0.406 \\
\hline Abscess & $5(0.8)$ & $2(0.4)$ & $7(0.6)$ & $1(0.5)$ & $4(0.9)$ & $5(0.8)$ & 9.0083 & 0.109 & 0.00 & $2(0.6)$ & $2(0.4)$ & & \\
\hline $\begin{array}{c}\text { Cysticercus } \\
\text { ovis }\end{array}$ & $7(1.2)$ & $4(0.8)$ & $11(1.1)$ & $2(1)$ & $5(1.5)$ & $7(1.6)$ & 0.5032 & 0.438 & $1(0.7)$ & $3(0.9)$ & $4(0.8)$ & 0.0248 & 0.875 \\
\hline Other & $15(2.5)$ & $18(3.8)$ & $33(3.4)$ & $2(1)$ & $13(3.9)$ & 15 & & & $2(1.5)$ & $16(2.4)$ & $18(3.4)$ & & \\
\hline overall & $70(11.6)$ & $60(13.2)$ & $130(12.3)$ & $18(9.3)$ & $42(10.3)$ & $70(11.6)$ & & & $11(8.5)$ & $49(15.2)$ & $60(13.2)$ & & \\
\hline
\end{tabular}

Table 5: Frequency and percentage lesions causing heart condemnation.

organ and carcass condemnation at Addis Ababa abattoir enterprise was estimated at 998,430.8 Ethiopian Birr. This total loss could be due to diseases and human factors either as a result of mishandling animals during transports to the slaughterhouse or due to faulty slaughter operations in the abattoir. 


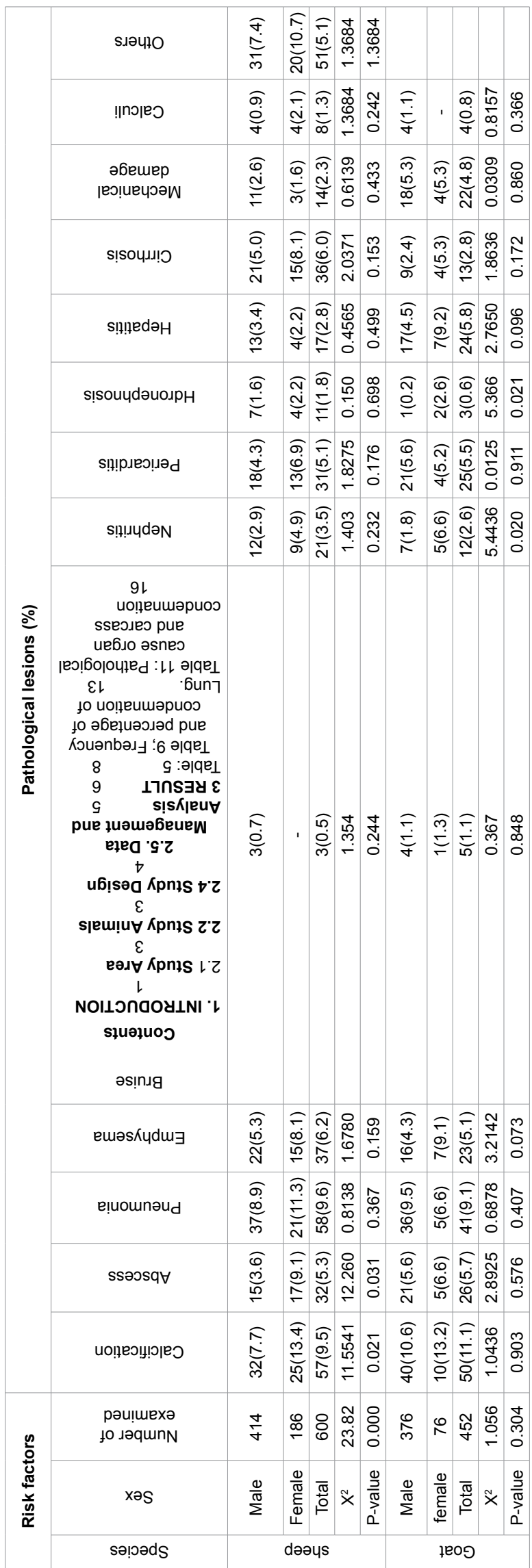

\section{Discussion}

The present study revealed that parasite and poor management practices are the major causes of organ and carcass condemnations. Parasitic causes like Fasciola species, Hydatid cyst, Stilesia hepatica and Cysticercus tenuicollis were found to be the major parasitic conditions responsible for organ condemnation. Even it impossible to draw back the origin of animal the frequency occurrence of pathological abnormalities show that parasitic disease of sheep and goats are widely distributed through to out the country. The major managemental practice that rendered organ and carcasses unfit for human consumption were faulty evisceration and bruising of carcass mainly brought about by mishandling of animals during transportation to the slaughter houses. Pneumonia was the major cause of lung condemnation in both species. It is observed that animals transported on foot long distance suffer from transportation stress and lack of feed and water. Those which were transported on open trucks are over crowed. Furthermore, animals are suffocated at the lairages and there was short resting time before slaughter for the animals to recover from physical stresses. Those conditions were causes of pneumonia and emphysema an observed at a higher case of incidence in this study. This indicates also violations of animal welfare stretching from farm to slaughter houses. The higher rate of occurrence of pneumonic lungs and poor meat quality are related to mishandling.

Liver condemnations are generally associated with infections of public health importance and for aesthetic reasons [13]. More than half of liver were condemned due to parasites; the rate of livers condemned in this study was relatively higher than a report in Debre Zeit HELMEX abattoir by Ejeta et al. [14] where $9.7 \%$ was recorded and a report in Kenya [15]. Mungube et al. have also reported frequency of liver condemnation due to Fasciola in goats at a rate of $6.6 \%$ which is lower than present finding $7.3 \%$. The higher rate of fasciolosis observed in sheep in comparison with goat could be due to their feeding behavior where sheep are usually grazers and goat tend to be more of browsers making them less exposed to parasites. Mungube et al. have also reported cumulative incidence of liver condemnation due to Stilesia hepatica at $28 \%$ and $22 \%$ in sheep and goats respectively, which is higher than the result obtained in this study ( $4.33 \%$ and $3.98 \%$ in sheep and goats, respectively) and also Ejeta et al. reported higher incidence rate of liver condemnation due to Stilesia hepatica at 9.5\% and $12.1 \%$ in sheep and goats, respectively. Ejeta et al. have also reported cumulative incidence of liver condemnation due to Cysticercus tenuicollis at 5.2\% and $8.3 \%$ in sheep and goats, respectively, which is higher than the result obtained in this study $(4.33 \%$ and $5.31 \%$ in sheep and goat, respectively) [14]. The epidemiology of S. hepatica and C. tenuicollis was not well established in sheep and goats; hence, it may be difficult to explain why significantly more livers were condemned in goats than in sheep. However Bekele et al. have reported a prevalence rate of $37.1 \%$ C. tenuicollis in sheep slaughtered at Addis Ababa Abattoir which higher than the present report in sheep (4.2\%) [16]. This may be due to increase the health services in the conditions in the country. One-tenth of the total condemned livers were due to mechanical damage that was caused by faulty practices during evisceration. Higher frequency of mechanical damage was observed in young animals than adults which might be related to the difficulty associated with the removal of liver from the thoracic cavity.

The presence of small ruminant hydatidosis at slaughter house has been documented in Ethiopia. Bekele et al. reported a prevalence rate of $16.4 \%$ in sheep which is higher than the finding in this study [16]. Similarly Jobre et al. reported prevalence rate of $11 \%$ and $6 \%$ from 
Citation: Assefa D, Gezaheng E, Abera B, Eticha E, Lemma D, et al. (2017) Major Cause of Organ and Carcass Condemnation in Apparently Healthy Small Ruminant Slaughtered at Addis Ababa Abattoir Enterprise, Ethiopia. J Vet Sci Technol 8: 419. doi: 10.4172/2157-7579.1000419

Page 6 of 7

\begin{tabular}{|c|c|c|c|c|c|c|c|}
\hline \multicolumn{3}{|c|}{ Risk factors } & \multicolumn{5}{|c|}{ PARASITOLOGICAL LESIONS } \\
\hline Species & Age & $\begin{array}{l}\text { No. of Examined } \\
\text { animal }\end{array}$ & Fasciola n (\%) & $\begin{array}{c}\text { Stilesia hepatica } \\
\mathrm{n}(\%)\end{array}$ & $\begin{array}{c}\text { Cysticercus tenicollis n } \\
(\%)\end{array}$ & Hydatid cyst $\mathrm{n}(\%)$ & Cysticercus ovis $\mathrm{n}(\%)$ \\
\hline \multirow{5}{*}{$\begin{array}{l}\text { बे } \\
\frac{\Phi}{\omega}\end{array}$} & Young & 193 & $18(9.33)$ & $6(3.11)$ & $11(5.69)$ & $10(5.18$ & $2(1.04)$ \\
\hline & Adult & 407 & $52(12.78)$ & $20(4.91)$ & $15(3.69)$ & 40(9.83) & $5(1.23)$ \\
\hline & Total & 600 & $70(11.67)$ & $26(4.33)$ & $26(4.33)$ & $50(8.33)$ & $7(1.17)$ \\
\hline & $X^{2}$ & & $1.512 \mathrm{o}$ & 1.0291 & 2.2057 & & 0.0420 \\
\hline & P-value & & 0.219 & 0.310 & 0.332 & & 0.838 \\
\hline \multirow{5}{*}{$\begin{array}{l}\mathbb{\pi} \\
\text { ס }\end{array}$} & Young & 129 & $7(5.43)$ & $6(4.65)$ & $5(3.88)$ & $7(5.43)$ & $1(0.78)$ \\
\hline & Adult & 323 & $26(8.05)$ & $12(3.72)$ & 19(5.88) & $28(8.67)$ & $3(0.93)$ \\
\hline & Total & 452 & $33(7.30)$ & 18(3.98) & $24(5.31)$ & $35(7.74)$ & $4(0.88)$ \\
\hline & $\mathrm{X}^{2}$ & & 0.9373 & 0.2112 & 0.7381 & & 0.0248 \\
\hline & P-value & & 0.333 & 0.646 & 0.390 & & 0.875 \\
\hline Overall & 1052 & & & & & & \\
\hline
\end{tabular}

Table 7: Parasitological causes of organ condemnation.

south Omo and Debre Zeit slaughter houses, respectively in sheep and goats which is similar with the present finding ( $8 \%$ and $9.78 \%$ in sheep and goat, respectively) [8].

In present finding, hydatid cysts were more frequently observed in lungs than liver of sheep and goats. Additionally similar findings were reported also reported by different authors [17-19]. However, the most common site for hydatid cyst was the liver followed by the lungs in the Middle East [20].

Bruising caused more than one-fourth of all carcasses condemned. Bruising occurs due to use of rough vehicles and beating of animals during transportation. Bruising also caused by excessive uses of sticks while driving to the abattoir, mishandling of animals during loading and unloading, improper transport vehicle where responsible causes at slaughter. Bruising could be also a result of in the slaughter houses when animals struggle during slaughter as stunning of small ruminants was not practiced at Addis Ababa abattoir in particularly and in other abattoir in Ethiopia in general [21]. It has been suggested that bruising during transportation is the major sources of economic loss in Africa and Asia [22].

Abscess, calcification, cirrhosis, nephritis and pericarditis important causes for the condemnation of edible organs like liver, heart and kidney [23]. Ojo reported similar cases in Nigeria and was able to isolate bacteria with public health significance. Salmonella serotypes $14.5 \%$ of mutton samples examined from various super markets in Addis Ababa reported [14].

Though Cysrticercus tenuicollis, Cysticercus ovis and Stilesia hepatica do not have public health importance, they are considered as important causes of economic loss, since viscera harboring them are rejected for economic loss and aesthetic reasons. The threat these parasites pose to small ruminant's meat industry in Ethiopia is evident due to the present situation of improper disposal of offal at abattoirs and backyard slaughter. The presence of freely roaming/living stray dogs on grazing land together with live stock and the deep rooted habit of feeding dogs with offal are important risk factors. This may lead to perpetuation of the life cycle between intermediate hosts (ruminants) and the final host dogs for C. ovis, C. tenuicollis and hydatidosis.

The financial loss in the abattoir is considered high. However, realization of the total (true) economic loss from organ and carcass condemnation is difficult and complex. The indirect losses from mortality at the lairage and public health implication were not included in the analysis in this study. Thus, the total economic loss attributable to diseases of small ruminants and hence, abattoir wastage could be much higher. The economic analysis of livestock disease in Ethiopia is scarce and inadequate because of lack of information on the prevalence and partly by the complexity of the analysis. Ngategize et al. reported a financial loss associated with liver condemnation due to ovine fasciolosis alone in the central highlands of Ethiopia amounting to be 2-3 million Ethiopian Birr (460.000 USD) [24]. Similarly Jobre et al. have estimated a total annual loss of 1.3 million Ethiopian Birr (260.000 USD) resulting from offal condemnation and carcass weight loss [8].

\section{Conclusion and Recommendations}

Slaughter houses provide excellent opportunities for detecting disease of both economic and public health importance. Government and other programs in Africa can use abattoirs as a source of data to assist in monitoring diseases, provide feedback to producer, to produce whole some products and to protect the public from zoonotic hazards. The present survey report indicates that parasitic disease, other pathological conditions, mechanical damage evisceration and bruising were the major cause of organ and carcass condemnation and financial loss through organ at Addis Ababa abattoir enterprise, which may also reflect the same scenario in other slaughter houses in Ethiopia. To mitigate the economic and public health impacts of diseases of small ruminants, proper disposal of offal, prohibition of backyard slaughter of small ruminants and construction of slaughter houses, better disease control strategies, adequate training of abattoir personnel on the slaughtering operation and regular deworming of stray and home dogs and Education of small ruminant traders how to transport the livestock from farm to markets recommendations are forwarded.

\section{Competing Interest}

The authors declare that they have no competing interest.

\section{Acknowledgements}

Authors I would like to thank the entire staff members of Addis Ababa abattoir enterprise and administrative office for their cooperation and support of this work.

\section{References}

1. Alemu Y, Merkel RC (2008) Sheep and Goat Production Handbook for Ethiopia: Ethiopia Sheep and Goat Productivity Improvement Program /ESGPIP/, Ministry of Agriculture and Rural Development, pp: 15-53

2. CSA (2016) Federal Democratic Republic of Ethiopia Central Statistical Agency Agricultural Sample Survey 2015/16 Volume II Report on livestock and livestock characteristics. Statistical Bulletin, p: 532.

3. Jacob L (1979) Seminar for Animal Health Officials. Minster of Agriculture and Settlement, Animals and Fisheries Authority, Addis Ababa, Ethiopia. 
Citation: Assefa D, Gezaheng E, Abera B, Eticha E, Lemma D, et al. (2017) Major Cause of Organ and Carcass Condemnation in Apparently Healthy Small Ruminant Slaughtered at Addis Ababa Abattoir Enterprise, Ethiopia. J Vet Sci Technol 8: 419. doi: 10.4172/2157-7579.1000419

4. Jibat T, Ejeta G, Asfaw Y, Wudie A (2008) Causes of Abattori condemnation in apparently healthy slaughtered sheep and Goats at HELMEX (Hashim Nurs' Ethiopian Livestock and Meat Export) abattoir at Debre Zeit, Ethiopia. Revue Med Vet. 5: 305-311.

5. Arbabi M, Hooshyr H (2006) Survey of Regions might have accounted for variation of the Echinococcosis and Hydatidosis in Kashan Region, Prevalence in different areas of a country Central Iran. Iran J Public Health 35: 75-81.

6. Fufa A, Loma A, Bekele M, Alemayehu R (2010) Bovine fasciolosis: coprological, abattoir survey and its economic impact due to liver condemnation at Sodo Municipal abattoir, Southern Ethiopia. Trop Anim Health Prod. 42: 289-292.

7. Herenda D, Chambers PG, Ettriqui A, Senevirat Nap, da Silva TJP (1994) Manual on meat inspection for developing countries, Food and Agricultura Organization of the united nations (FAO), Rome, Italy.

8. Jobre Y, Lobago F, Tiruneh R, Abebe G, Dorchies PH (1996) Hydatidosis in three Selection Region in Ethiopia: An Assessment Trial on its Prevalence, Economic and Public Health Importance. Revue med Vet. 147: 797-804.

9. LMA (2009) Brief baseline information on Ethiopian livestock resources base and its trade, livestock Marketing Authority, Addis Ababa, Ethiopia.

10. NMA (2011) National Meteorology Service Agency. Addis Ababa, Ethiopia.

11. Steele M (1996) Goats: The tropical Agriculturist. Macmillan Education Ltd, CTA Publishing, London, pp: 79-83.

12. Ogunrinade A, Ogunrinade $\mathrm{BI}$ (1980) Economic importance of bovine fasiolosis in Nigeria. Trop Anim Prod. 12: 155-160.

13. Edwards DS, Johnston AM, Mead GC (1997) Meat Inspection and Overview of Present Practice and Future Trends. Vet J. 154: 135-147.

14. Ejeta G, Molla B, Alemayehu D, Muckle A (2008) Salmonella serotypes isolated from minced beef, mutton and pork in Addis Ababa Ethiopia. Revue Med Vet. 155: $547-551$.
15. Mungube EO, Bauni SM, Tenhagen BA, Wamael W, Nyinyi JM, et al. (2006) The prevalence and econmic significance of Fasciola gigantica and stelesia hepatica in slaughtered animals in semi-arid costal Kenya. Trop Anim HIth Prod. 38: 475-483.

16. Bekele T, Mukassa ME, Kasali OB (1988) The prevalence of cysticercosis and Hydatidosis in Ethiopian sheep. Vet Parasitol. 28: 267-270.

17. Khan AH, El-Buni AA, Ali MY (2001) Fertility of the Cyst of Echinococcus Granulosus in Domestic Herbiivorse from Benghazi, Libya, and the Ractivityof Antigens Produced from them. Ann Trop Med Parasitol. 95: 337-342.

18. Dalimai A, Motamedi GH, Hosseini M, Mohammadian B, Malaki H, et al. (2002) Echinococcosis/hydatidosis in western Iran. Vet Parasitol. 105: 161-171.

19. Daryani A, Alaei R, Arab R, Sharif M, Dehghan MH, et al. (2007) The Prevalence, Intensity and Viability of Hdatidcysts in Slaughtered Animals in the Ardavil Province Northwest Iran. J Helminthol. 81: 13-17.

20. Kamhawi S, Hijjawi N, Abu-Ghazaleh A, Abbas M (1996) Pevalence of Hydatid Cyst in Livestock from Five Regions in Jorda. Ann Trop Med Hyg. 147: 797-804.

21. Gracey JF, Collins OS, Hueyr J (1999) Meat hygiene. Tenth Edition, Baillier Tindall, London Philadelphia, Toronto, pp. 223-260.

22. Mitchell JR, Slough CAB (1980) Guide to Meat inspection in the Tropics, Common Wealth Bureau of Animal Health, UK

23. Ojo SA (1996) Survey of Pathological Conditions in Slaughtred Goats at Zaria Slaughter houses. In: Lebbie SHB, Kagwini E (eds). Small Ruminant Research and Development in Africa. Proceeding of the Third Biennial conference of the African small ruminant Research network, UICC, Kampala, Uganda, 5-9 December 1994 International Livestock Research Institute (ILIRI), Nairobi, Kenya.

24. Ngategize PK, Bekele T, Tilahun G (1993) Financial Losses caused by Ovine Fasciolosis in the Ethiopian Highlands. Trop Anim Health Prod. 25: 155-161. 